\title{
Cyano-Aryl Porphyrazine Pigments with Polycyclic Substituents as the Promising Agents for Photodynamic Therapy and Potential Sensors of Local Viscosity
}

Svetlana A. Lermontova, ${ }^{a}{ }$ Ilya S. Grigoryev, ${ }^{a}$ Nina N. Peskova, ${ }^{\text {b }}$ Elena Yu. Ladilina, ${ }^{a}$ Tatyana S. Lyubova, ${ }^{a}$ Vladimir I. Plekhanov, ${ }^{\mathrm{c}}$ Ivan D. Grishin, ${ }^{\mathrm{b}}$ Irina V. Balalaeva, ${ }^{\mathrm{b}}$ and Larisa G. Klapshina ${ }^{\mathrm{a}, \mathrm{b}} @$

Dedicated to Professor Dieter Wöhrle on the occasion of his 80th Anniversary

${ }^{a}$ G.A. Razuvaev Institute of Organometallic Chemistry of RAS, 603950 Nizhny Novgorod, Russia

${ }^{\mathrm{b}}$ N.I. Lobachevsky State University of Nizhny Novgorod, 603950 Nizhny Novgorod, Russia

'Institute of Applied Physics of RAS, 603950 Nizhny Novgorod, Russia

@Corresponding author E-mail: klarisa@iomc.ras.ru

The unique cyanoporphyrazine pigment with four bulky phenanthrenyl peripheral substituents has been prepared. It demonstrates the noticeable shift of $Q$-band to longer wavelengths due to phenanthryl aromatic system extension. The compound showed very strong predominance of photoinduced cytotoxicity over cytotoxicity in the dark. The presented results indicate the enhancement of photodynamic properties of porphyrazine containing polycyclic aryl substituents in peripheral framing. It is confirmed that the chemical design of the peripheral aryl groups is an efficient toolkit for a fine tuning of photodynamic properties. Furthermore, we have shown that in spite of the presence of bulky substituents new cyano-aryl porphyrazine demonstrates the properties of fluorescent molecular rotors, i.e. the segmental intramolecular mobility in environment of low viscosity. Previously on the example of related cyano-aryl porphyrazines combining the properties of fluorescent molecular rotors and photosensitizers we have demonstrated high potential of these compounds as the sensors of local viscosity and rigidity of biological submicrometer environment within a living cell. So, in respect to PDT it can be a significant expansion of photosensitizer functionality as a potential agent of optical theranostics.

Keywords: Porphyrazine pigments, photoinduced cytotoxicity, photodynamic therapy, fluorescent molecular rotors.

\section{Циано-арил порфиразиновые пигменты с полициклическими заместителями как перспективные агенты Аля фотодинамической терапии и потенциальные сенсоры локальной вязкости}

\author{
С. А. Лермонтова, ${ }^{a}$ И. С. Григорьев, ${ }_{1}^{\text {a }}$ Н. Н. Пескова, ${ }_{1}^{\text {b }}$ Е. Ю. Ладилина, ${ }^{a}$ \\ Т. С. Аюбова, ${ }^{\text {a }}$ В. И. Плеханов, ${ }^{c}$ И. А. Гришин, ${ }^{\text {b }}$ И. В. Балалаева, ${ }^{\mathrm{b}}$ \\ А. Г. Клапшина ${ }^{\mathrm{a} b @}$
}

\footnotetext{
а Институт металлоорганической химии им. Г.А. Разуваева РАН, 603950 Нижний Новгород, Россия

${ }^{\mathrm{b}}$ Нижегородский государственный университет им. Н.И. Лобачевского, 603950 Нижний Новгород, Россия

'Институт прикладной физики РАН, 603950 Нижний Новгород, Россия

${ }^{\circledR}$ E-mail: klarisa@iomc.ras.ru
}

Получен новый уникальный цианопорфиразиновый пигмент с четырьмя объемными фенантрильными заместителями в периферическом обрамлении макрочикла. Расширение ароматической системь 
макрочикла обеспечивает заметное смещчение Q-полосы в длинноволновую область. Соединение показало многократное преобладание фотоиндуцированной циттотоксичности над ичитотоксичностью в темноте. Представленные результаты свидетельствуют об улучшении фотодинамических свойств порфиразина, содержащего полициклические арильные заместители в периферическом каркасе. Кроме того, несмотря на наличие объемных заместителей, порфиразин сохраняет свойства флуорофоров, демонстрирующих сильную зависимость фотофизических параметров (квантового выхода и времени жизни флуоресценции) от локальной вязкости среды (флуоресцентных молекулярных роторов). Эти флуорофоры характеризуются повышенной мобильностью отдельных фрагментов молекульы в результате возбуждения светом в низковязких средах, что приводит к частичной диссипации энергии фотовозбуждения. Высокая чувствительность параметров флуоресиенции цุиано-арильных порфиразинов к локальной вязкости может быть использована для оптического зондирования вязкостных свойств биологических сред, в том числе и живых клеток. Известно, что внутриклеточная вязкость является одним из важнейших показателей функционального состояния живых клеток и протекающих в них разнообразных динамических прочессов. Ранее на примере близких по строению циино-арил порфиразинов было показано, что сочетание свойств высокоэффективного фотосенсибилизатора для ФДТ и чувствительного оптического сенсора внутриклеточной вязкости позволяет значительно расширить функциональность порфиразина как потенциального агента оптической тераностики. Представленные результаты подтвердили, что химический дизайн периферических арильньх групп является эффективным инструментарием для тонкой настройки фотодинамических свойств.

Ключевые слова: Порфиразины, фотоиндуцированная цитотоксичность, фотодинамическая терапия, флуоресцентный молекулярный ротор.

\section{Introduction}

Tetrapyrrolic pigments are considered to occupy a central role in the modern bioorganic chemistry since they display highly delocalized $\pi$-electron systems which confer distinct optical properties, prompting the study of these molecules as optical agents in biological systems, e.g., in photodynamic therapy (PDT). PDT is a minimally invasive therapeutic modality approved for treatment of cancer diseases and some non-oncological disorders. ${ }^{[1-5]}$

This approach is based on the local or systemic administration and the selective accumulation and/or retention of a photosensitizing agent (photosensitizer) in tumor tissue followed by irradiation with visible light of a wavelength matching the absorption spectrum of the photosensitizer (therapeutic window: 600-800 $\mathrm{nm}$ ). The tetrapyrrolic pigments such as porphyrins and chlorins have been long studied as photodynamic therapy (PDT) agents due to their light activated production of strongly cytotoxic singlet oxygen. ${ }^{[6-7]}$

It should be noted that the structurally related porphyrazine pigments with their four meso-carbons replaced by aza linkages had attracted the attention as the efficient photosensitizers in PDT much later. Nevertheless, it emerged rather quickly that porphyrazines are a very important class of tetrapyrroles suitable for PDT with excellent uptake and retention properties in vivo. ${ }^{[8-10]}$

During the last several years we have developed a series of cyano-aryl porphyrazines (Figure 1) which can be modified by a variation of the peripheral aryl substituents in $\beta$-position of porphyrazine core pyrroles. We have found that the structure of peripheral aryl groups coupled with macrocycle core significantly affects photophysical and cytotoxic properties of porphyrazines..$^{[11-13]}$ So, the porphyrazine peripheral framing variation can be used as an effective tool for a therapeutic potential fine tuning.

In the present paper, we report the new cyano-aryl porphyrazine with peripheral polycyclic aryl $\beta$-substituent (phenanthryl) which demonstrates extraordinary high potential therapeutic index (the ratio cytotoxicity in the dark and under irradiation with light). In addition, we have established the noticeable correlation between potential photodynamic effectiveness and aryl substituent aromatic $\pi$-systems expansion that, presumably, causes their higher coupling with macrocyclic core: ratio $\mathrm{IC}_{50}$ (dark)/ $/ \mathrm{IC}_{50}$ (light) or so-called potential therapeutic index strongly increases in the row $\mathbf{p z I} \rightarrow \mathbf{p z I I} \rightarrow \mathbf{p z I I I} \rightarrow \mathbf{p z I V}$.

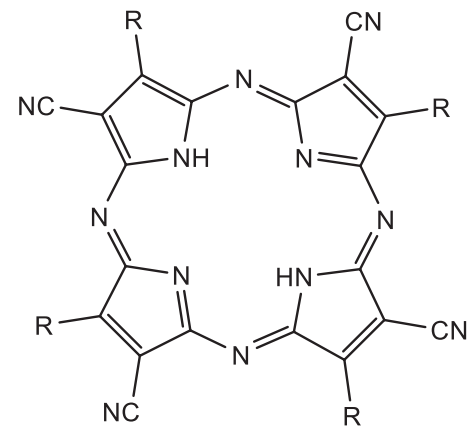

$\mathrm{R}=$<smiles>Cc1ccc(F)cc1</smiles><smiles>Cc1ccc(-c2ccccc2)cc1</smiles><smiles>Cc1ccc2ccccc2c1</smiles><smiles>Cc1cc2ccccc2c2ccccc12</smiles>

Figure 1. The structure of cyano-aryl porphyrazines pzI-pzIV. 
We also report the first published data on the dependence of the fluorescence parameters of these porphyrazines (fluorescence lifetime and quantum yield) on environment viscosity, which confirm that prepared porphyrazine pigments belong to the family of fluorophores termed "fluorescent molecular rotors".

\section{Experimental}

The solvents and reagents were used as received from Sigma-Aldrich, without further purification. ${ }^{1} \mathrm{H}$ and ${ }^{13} \mathrm{C}$ NMR spectra were recorded on a Brucker Avance DPX-200 spectrometer (200 MHz and $50 \mathrm{MHz}$, respectively). All chemical shifts were referenced to TMS lock signal. UV-Vis electron absorption spectra of the compounds were recorded using a Perkin Elmer Lambda 25 spectrometer. IR spectra in the form of mineral oil suspensions were recorded using an FSM 1201 spectrometer. Fluorescence was studied in a stationary mode using a Perkin Elmer LS 55 spectrometer at $300-800 \mathrm{~nm}$. Positive ion electron ionization mass spectra were measured on a PolarisQ/TraceGCUltra GC/ MS spectrometer at $70 \mathrm{eV}$, by temperature of ion source $230{ }^{\circ} \mathrm{C}$ by heating the sample from 50 to $450{ }^{\circ} \mathrm{C}$ in the mass number range of 90-600. MALDI-TOF mass-spectra of the compound 4 (Scheme 1) were obtained on a Bruker Microflex LT instrument using HCCA as a matrix and a ground steel target plate. The mass spectrum of the compound pzIV was recorded in LDI experiment using ground steel target plate with no matrix addition.

\section{Synthesis}

Synthesis of pzI-pzIII was carried out by the method previously described. ${ }^{[11,14]}$ PzIV was prepared according to Scheme 1.

2-(Phenanthren-9-ylmethylene)malononitrile (1). Malononitrile $(0.48 \mathrm{~g}, 7.3 \mathrm{mmol})$ and a few drops of piperidine were added to 9-phenanthrenecarboxaldehyde $(1.50 \mathrm{~g}, 7.3 \mathrm{mmol})$ in ethanol $(100 \mathrm{~mL})$. The reaction mixture was stirred for $24 \mathrm{~h}$ at room temperature. The residue was separated using filter of Schott and dried under vacuum to yield compound $\mathbf{1}$ as yellow crystals (1.66 g, $6.5 \mathrm{mmol}, 90 \%$ yield). EI MS (70 eV) $\mathrm{m} / \mathrm{z}(\%) 254(100)\left[(\mathrm{M})^{+}\right]$. IR $(\mathrm{KBr}) v_{\max } \mathrm{cm}^{-1}: 3080(\operatorname{arC}-\mathrm{H}), 3028(=\mathrm{CH}), 2226(\mathrm{C} \equiv \mathrm{N}), 1568$ (arC-C), 740, 721. ${ }^{1} \mathrm{H}$ NMR $\left(\mathrm{CDCl}_{3}\right) \delta_{\mathrm{H}} \mathrm{ppm}: 7.65-7.86(4 \mathrm{H}, \mathrm{m})$, 7.91-8.03 (2H, m), $8.46(1 \mathrm{H}, \mathrm{s}), 8.62(1 \mathrm{H}, \mathrm{s}), 8.67-8.77(2 \mathrm{H}, \mathrm{m})$.
2-(Phenanthren-9-yl)ethane-1,1,2-tricarbonitrile (2). A solution of potassium cyanide $(0.80 \mathrm{~g}, 12.2 \mathrm{mmol})$ in cold water $(80 \mathrm{~mL})$ was added to $1(1.56 \mathrm{~g}, 6.1 \mathrm{~mol})$ dissolved in ethanol $(100 \mathrm{~mL})$. Then, the reaction mixture was diluted with cold water $(700 \mathrm{~mL})$, stirred for $45 \mathrm{~min}$ at room temperature and concentrated $\mathrm{HCl}$ was added $(1.7 \mathrm{~mL})$. After $15 \mathrm{~min}$, the resulting mixture was refrigerated at $8{ }^{\circ} \mathrm{C}$ for $12 \mathrm{~h}$. The precipitate was filtered off, carefully washed with water and dried under vacuum to yield white crystals of compound 2 (1.66 g, $5.9 \mathrm{mmol}, 96 \%$ yield). EI MS (70 eV) $\mathrm{m} / z$ (\%) 305 (8) $\left[(\mathrm{M})^{+}\right], 306(2)\left[(\mathrm{M}+1)^{+}\right], 278(100)\left[(\mathrm{M}-\mathrm{HCN})^{+}\right] . \mathrm{IR}(\mathrm{KBr}) v_{\max } \mathrm{cm}^{-1}$ : 3087 (arC-H), 3025, 2929, 2921 (-CH-), 2254 (C $\equiv \mathrm{N}), 1646$ (arC-C), 1604, 797, 767. ${ }^{1} \mathrm{H}$ NMR $\left(\mathrm{CDCl}_{3}\right) \delta_{\mathrm{H}} \mathrm{ppm}: 4.47(1 \mathrm{H}, \mathrm{d}, J=4.6 \mathrm{~Hz})$, $5.32(1 \mathrm{H}, \mathrm{d}, J=4.8 \mathrm{~Hz}), 7.71-7.85(5 \mathrm{H}, \mathrm{m}), 8.01-8.07(1 \mathrm{H}, \mathrm{m}), 8.25$ $(1 \mathrm{H}, \mathrm{s}), 8.69-8.88(2 \mathrm{H}, \mathrm{m})$.

2-(Phenanthren-9-yl)ethene-1,1,2-tricarbonitrile (3). Chlorosuccinimide (1.06 g, $8 \mathrm{mmol})$ was added to $2(1.6 \mathrm{~g}, 5.7 \mathrm{mmol})$ in diethyl ether $(100 \mathrm{~mL})$. After $1 \mathrm{~h}, 150 \mathrm{~mL}$ of water was added. The mixture was stirred until precipitation of a solid. The precipitate was filtered off and dried. The resulting product was purified by sublimation to yield orange crystals of $\mathbf{3}(1.37 \mathrm{~g}, 4.9 \mathrm{mmol}$, $86 \%$ yield). EI MS (70 eV) m/z (\%) $279(70)\left[(\mathrm{M})^{+}\right], 253(100)$ $\left[(\mathrm{M}-\mathrm{CN})^{+}\right]$. IR $(\mathrm{KBr}) v_{\max } \mathrm{cm}^{-1}: 3069(\operatorname{arC}-\mathrm{H}), 2238(\mathrm{C} \equiv \mathrm{N}), 1614$ (arC-C), 752, 725. ${ }^{1} \mathrm{H}$ NMR $\left(\mathrm{CDCl}_{3}\right) \delta_{\mathrm{H}} \mathrm{ppm}: 7.69-8.06(7 \mathrm{H}, \mathrm{m})$, 8.71-8.82 (2H, m). ${ }^{13} \mathrm{C}$ NMR (50 MHz, $\left.\mathrm{CDCl}_{3}\right) \delta_{\mathrm{C}} \mathrm{ppm}: 100.75$, $110.55,111.30,114.07,116.83,121.70,122.42,123.50,124.74$, $125.69,126.58,127.15,128.84,129.73,130.28,130.69,131.96$, 133.91, 142.04 .

3,8,13,18-Tetra(phenanthren-9-yl)-2,7,12,17-tetracyanoporphyrazinate $\mathrm{Yb}(\mathrm{III})$ hydroxide (4). Compound 3 (0.48 g, $1.70 \mathrm{mmol})$ in THF $(10 \mathrm{~mL})$ and bis-indenyl ytterbium $(0.19 \mathrm{~g}$, $0.35 \mathrm{mmol})$ in THF $(2 \mathrm{~mL})$ were mixed under vacuum. After $24 \mathrm{~h}$, the solution was filtered under vacuum. To remove the unreacted compound $\mathbf{3}$ and its complex with ytterbium, the obtained solution was washed with degassed toluene until discoloration. The product was dried under reduced pressure $(0.250 \mathrm{~g}, 0.19 \mathrm{mmol}, 55 \%$ yield $)$ Anal. calcd. for $\mathrm{C}_{76} \mathrm{H}_{37} \mathrm{~N}_{12} \mathrm{OYb}$ : C 69.83, H 2.85, N $12.86 \%$. Found: C 69.67, H 2.92, N 12.98 \%. MS (MALDI-TOF) 621.0 (calcd. for $\left.\left[(\mathrm{M}-2 \mathrm{CN})^{2+}\right] 620.1\right), 650.1$ (calcd. for $\left.\left[\left(\mathrm{M}+2 \mathrm{H}_{2} \mathrm{O}-\mathrm{CN}\right)^{2+}\right] 651.1\right)$, 673.0 (calcd. for $\left[\left(\mathrm{M}+3 \mathrm{H}_{2} \mathrm{O}\right)^{2+}\right]$ 673.1). IR $(\mathrm{KBr}) v_{\max } \mathrm{cm}^{-1}: 2201$ $(\mathrm{C} \equiv \mathrm{N}), 1598,1573,1505,1482$.

3,8,13,18-Tetra(phenanthren-9-yl)-2,7,12,17-tetracyanoporphyrazine (pzIV). Complex 4 (125 $\mathrm{mg}, \quad 0.1 \mathrm{mmol})$ was dissolved in trifluoroacetic acid $(2 \mathrm{~mL})$ and stirred at room temperature for $30 \mathrm{~min}$. The resulting solution was poured onto

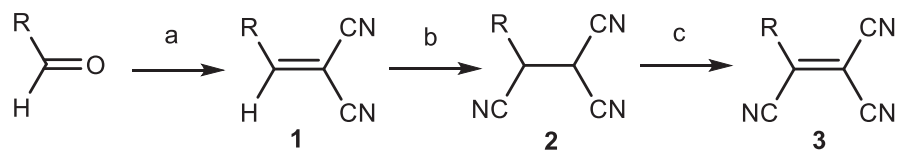<smiles></smiles>

Scheme 1. Synthesis of porphyrazine pzIV. a: malonodinitrile, piperidine EtOH, 24 h, RT; b: KCN, $\mathrm{H}_{2} \mathrm{O}, \mathrm{EtOH}, 45 \mathrm{~min}, \mathrm{RT}, \mathrm{HCl}$; c: chlorosuccinimide, $\mathrm{Et}_{2} \mathrm{O}$; d: bis-indenyl ytterbium, THF, $24 \mathrm{~h}$, vacuum; e: trifluoroacetic acid, 30 min, RT. 
ice/water $(30 \mathrm{~mL})$ and a dark-blue solid was precipitated. This residue was centrifuged and carefully washed with water until the supernatant gave a neutral reaction. The product was further purified by chromatography (Silica gel $60,40-63 \mu \mathrm{m}$ particle size, Sigma-Aldrich, THF eluent). The purification was repeated twice and gave the isolated pzIV as a dark blue solid (44 mg, $0.04 \mathrm{mmol}$, $41 \%$ yield). Anal. calcd. for $\mathrm{C}_{76} \mathrm{H}_{38} \mathrm{~N}_{12}: \mathrm{C} 81.56, \mathrm{H} 3.42, \mathrm{~N} 15.02 \%$. Found: C 81.39, H 3.54, N 15.15 \%. MS (MALDI-TOF): 558.6 (calcd. for $\left.\left[(\mathrm{M}-2 \mathrm{H})^{2+}\right] 558.5\right), 586.6$ (calcd. for $\left[\left(\mathrm{M}+3 \mathrm{H}_{2} \mathrm{O}\right)^{2+}\right]$ 586.5), 1066.2 (calcd. for $\left[(\mathrm{M}-\mathrm{HCN}-\mathrm{CN})^{2+}\right]$ 1066.4). IR (KBr) $v_{\max } \mathrm{cm}^{-1}: 3412(\mathrm{NH}), 3060\left(\mathrm{C}_{\mathrm{ar}} \mathrm{H}\right), 2202(\mathrm{C} \equiv \mathrm{N}), 1619,1595,1456$, 1450. ${ }^{1} \mathrm{H}$ NMR $\left(\mathrm{CD}_{3} \mathrm{CN}\right) \delta_{\mathrm{H}} \mathrm{ppm}: 6.09(\mathrm{~s}, 1 \mathrm{H},-\mathrm{NH}), 6.26(\mathrm{~s}, 1 \mathrm{H}$, -NH), 7.39-8.11 (m, 28H), 8.70-8.92 (m, 8H). ${ }^{13} \mathrm{C}$ NMR (50 MHz, $\left.\mathrm{CD}_{3} \mathrm{CN}\right) \delta_{\mathrm{C}}$ ppm: $65.6,67.3,68.5,120.3,121.5,121.9,122.9,123.3$, $125.8,127.5,128.0,129.1,130.2,130.4,130.6,131.0,132.9,133.0$, $135.7,135.9,162.9$

\section{Fluorescence Lifetime Measurements}

The series of fluorescence decay traces were measured at picoseconds time range by using time-correlated single photon counting (TCSPC) technique. The TCSPC system compound on the basis of SPC-130 photon counting card, PMC-100 PMT detector module with optical fiber input, and DCC-100 detector control card (Becker\&Hickl, GmbH) was used. Total acquisition time window is at $0-50 \mathrm{~ns}$ range with 1024 collection channels. The picoseconds fiber laser SC-450 (Fianium Ltd, UK) was used as a excitation source, with custom output spectral selection at range 580-595 nm by band-pass interference filter (Chroma Tech., USA). Fluorescence was detected at $640-700 \mathrm{~nm}$ spectral range by means of the domestic two lens detector head with optical fiber output, which was consist emission and neutral density filters set. The system instrument response function (IRF) was defined by recording a signal from high scattering media. Measurement IRF value of whole TCSPC system was 290 ps FWHM. Deconvolution by IRF and fitting of fluorescence decays to the suitable exponential model was done by using SPCImage software (Becker\&Hickl, GmbH), with further data processing by Excel. The decay time $\left(\tau_{\mathrm{f}}\right)$ were calculated as the average of the lifetimes of the decay components, which weighted to their integral intensities. Intensity weighted average lifetime $\tau_{\mathrm{f}}$ defined as:

$$
\tau_{\mathrm{f}}=\frac{\sum_{\mathrm{i}} \mathrm{a}_{\mathrm{i}} \tau_{\mathrm{i}}^{2}}{\sum_{\mathrm{i}} \mathrm{a}_{\mathrm{i}} \tau_{\mathrm{i}}}
$$

where $a_{i}$ and $\tau_{i}$ are the amplitudes and lifetimes of fitting components of the individual decay curve. All series of decays measurements were carried out in standard 96 well culture plates. The lab thermostat ThermoStat plus (Eppendorf, $\mathrm{GmbH}$ ) was used for set and control of wells surface temperature.

\section{Study of Cellular Uptake of pzI-pzIV}

Human epidermoid carcinoma A431 cells (from Russian Collection of Cell Cultures) were cultured at $37^{\circ} \mathrm{C}$ under $5 \% \mathrm{CO}_{2}$ in DMEM supplemented with $2 \mathrm{mM}$ glutamine and $10 \%$ FBS.

To study the dynamics of the uptake, culture medium in the plates was replaced with a medium containing $5 \mu \mathrm{M}$ pzIpzIV. Fluorescence from the cells was registered by a Synergy MX plate reader (BioTeck, USA) in 5-300 min after addition of the dye. Fluorescence was excited at a wavelength of $590 \mathrm{~nm}$ and recorded at $660 \mathrm{~nm}$ for pzI, pzIII or at $650 \mathrm{~nm}$ for pzII or at $655 \mathrm{~nm}$ for pzIV. The fluorescence signals were normalized to the value recorded from the medium with the corresponding compound without the cells. Data analysis was performed using the GraphPad Prism 6 software. All measurements were carried out in at keast three wells.
Cell images were obtained using laser scanning microscopy using Axio Obzerver Z1 LSM710 NLO Duo (Carl Zeiss, Germany) with $63 \times$ oil Plan-Apochromat objective with numerical aperture of 1.4. The pzI-pzIV fluorescence was excited with $633 \mathrm{~nm}$ laser and collected in the spectral range of $650-710 \mathrm{~nm}$.

For analysis of intracellular localization, the cells were incubated with pzIV at $5 \mu \mathrm{M}$ for 4 hours and then stained with the following dyes according to the manufacturer's instructions (ThermoFisherScientific): $0.5 \mu \mathrm{M}$ LysoTracker Green DND-26, $0.5 \mu \mathrm{M}$ ER-Tracker, $5 \mu \mathrm{M}$ BODIPY FL C5-ceramide complexed to BSA for Golgi apparatus. For mitochondria visualization, the genetically transformed A431 cells expressing mitochondriatargeted fluorescent protein HyPer-mito were used. Fluorescence of stained organelles was excited by an argon laser at $488 \mathrm{~nm}$ and registered in the range of 500-550 $\mathrm{nm}$.

\section{Study of Photodynamic Activity of pzI-pzIV in vitro}

The A431 cells were seeded in 96-well plates at a density of 4000 cells per well and were allowed to attach overnight $(20$ h). The medium was removed, and the cells were then incubated in the presence of pzI-pzIV at different concentrations in growth medium at $37{ }^{\circ} \mathrm{C}$ for $4 \mathrm{~h}$ in $5 \% \mathrm{CO}_{2}$. Then the cells were washed twice with PBS and the incubation medium with pzI-pzIV was replaced by growth medium. To estimate photoinduced toxicity, the cells were exposed to light irradiation $(615-635 \mathrm{~nm}$, $20 \mathrm{~mW} / \mathrm{cm}^{2}, 20 \mathrm{~J} / \mathrm{cm}^{2}$ ) using LED light source providing a homogeneous light distribution in 96 -well plates. ${ }^{[15]}$ Irradiated cells were then incubated for $24 \mathrm{~h}$ before cell viability was measured by the MTT assay. ${ }^{[16]}$ To this aim, 3-(4,5-dimethyl-2-thiasolyl)2,5-diphenyl-2H-tetrasole bromide (MTT reagent, Alfa Aesar, USA) was added to the growth medium in the final concentration of $0.5 \mathrm{mg} / \mathrm{mL}$ and the cells were incubated for 4 hours. Formazan formed from the reduction of MTT was dissolved in DMSO, and the absorbance was measured at $540 \mathrm{~nm}$ with a Synergy MX plate reader (BioTeck, USA). The amount of formazan produced is assumed to be proportional to the number of living cells. Cell viability was expressed as the ratio of the optical density of treated and untreated cells given in percents. The same procedure was applied for estimation of dark toxicity of $\mathrm{Pz}$, except that there was no cells exposure to LED light. Experiments were performed in triplicate and repeated at least three times. Data analysis and calculation of $\mathrm{IC}_{50}$ were performed using the GraphPad Prism 6 software.

\section{Results and Discussion}

To estimate the capacities of the new cyano-aryl porphyrazine pigment PzIV containing peripheral 9-phenanthrenyl substituents we have investigated the photophysical properties (Table 1) and quantified its dark and photoinduced cytotoxicity to compare them with the same characteristics for relate porphyrazines pzI-pzIII..$^{[1,13]}$

Absorption spectra of cyano-aryl porphyrazines pzI-pzIV are typical for non-associated porphyrazine macrocycles (Figure 2A). But the noticeable shift of $Q$-band to longer wavelengths due to aryl substituent aromatic system extension (particularly, for pzIV) had been observed. Such the shift towards the spectral region corresponding to greater optical transparency of the biological tissue is potentially very beneficial for photodynamic therapy efficiency. Fluorescence spectra maxima of pzII-pzIV are also strongly shifted to the longer wavelengths in comparison with that of pzI with single aromatic rings in the macrocycle framing. 
Table 1. Photophysical properties of pzI-pzIV in aqueous solutions: $\lambda_{\mathrm{abs}}$, $\lg \varepsilon, \lambda_{\mathrm{em}}$ and $\Phi$ refer to the maxima of absorption, fluorescence spectra, molar extinction coefficient and quantum yield, respectively, $[\mathrm{pz}]=5 \mu \mathrm{M}$.

\begin{tabular}{|c|c|c|c|c|c|c|}
\hline Porphyrazine & $\lambda_{\mathrm{abs}}(\mathrm{nm})$ & $\log \varepsilon$ & $\lambda_{\mathrm{em}}(\mathrm{nm})$ & $\Phi(\%)^{*}$ & $\alpha^{* *}$ & Ref. \\
\hline pzI & 580 & 4.60 & 650 & 0.3 & 0.64 & [13] \\
\hline pzII & 594 & 4.09 & 690 & 0.1 & 0.40 & [11] \\
\hline pzIII & 592 & 4.55 & 690 & 0.1 & 0.40 & [11] \\
\hline pzIV & $608,580(\mathrm{sh})$ & 4.41 & 680 & 0.3 & 0.40 & \\
\hline
\end{tabular}

$*$ Fluorescence quantum yields of pzI-pzIV, upon excitation at $580 \mathrm{~nm}$, are reported relative to cresyl violet perchlorate in $\mathrm{MeOH}\left(\Phi_{\mathrm{r}}=0.54\right),{ }^{[17]} * *$ The value of parameter $\alpha$ in Förster-Hoffman equations.
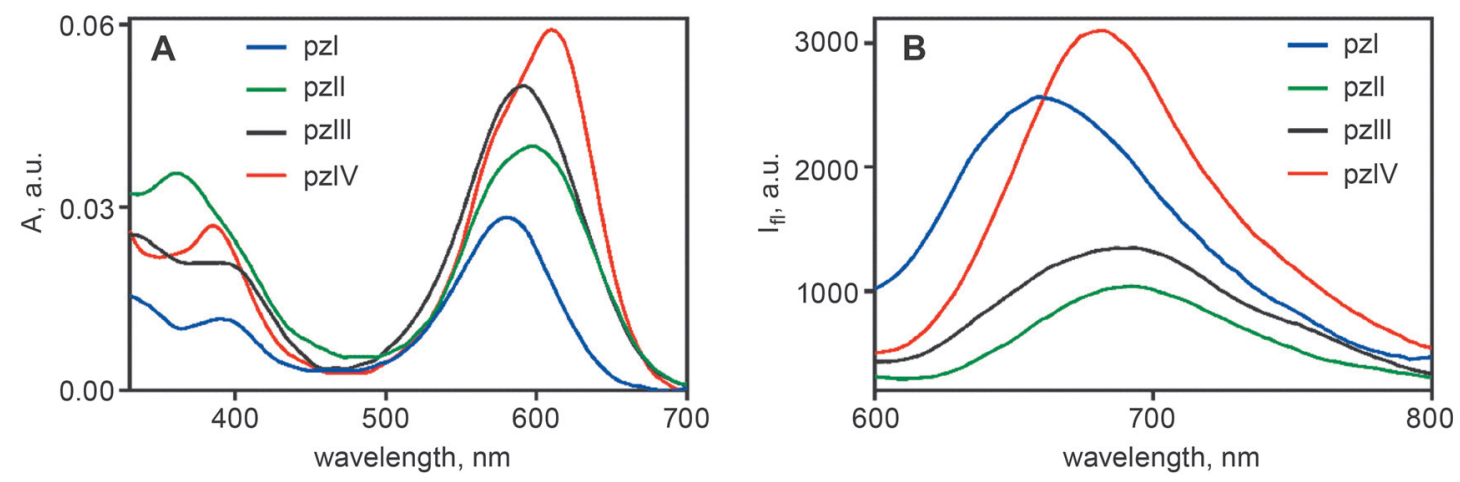

Figure 2. Normalized absorption (A) and fluorescence spectra (B) of pzI-pzIV in water $\left(\lambda_{\text {exc }}=590 \mathrm{~nm}\right)$.
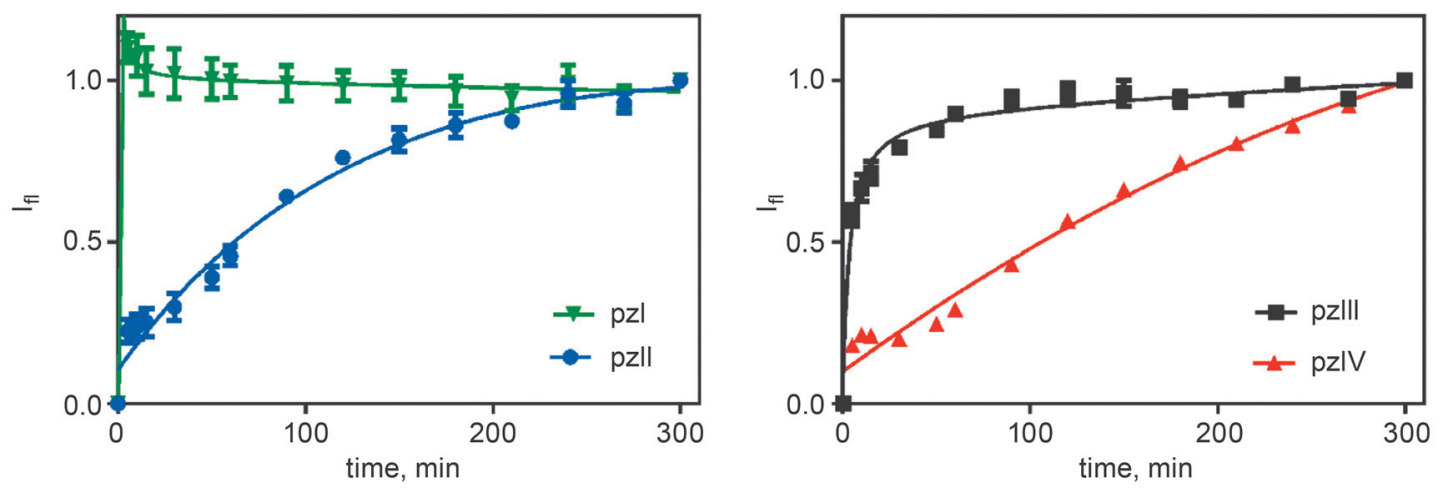

Figure 3. Accumulation of pzI-pzIV in A431 cells. Dependence of the cell fluorescence intensity on time.

The incubation of cultured human cancer cell (A431 cell line) in the medium containing pzI, pzII, pzIII and pzIV lead to an appearance of exogenous fluorescence of cells and its rise over time (Figure 3). It is seen that the accumulation rate of porphyrazines in cell strongly depends on aryl substituent structure. We observed very fast cellular uptake for pzI with the single aromatic rings at the peripheral framing. Accumulation of pzII with biphenyl substituents occurred significantly slower. The presence of polycyclic aromatic structures in pzIII and pzIV slowed down the cellular uptake considerably.

All four porphyrazines, including pzIV, show negligible emission in medium but they demonstrate a remarkable increase of the fluorescence signal in cells. The bright red fluorescence of $\mathbf{p z}$ in cells means that they are located in an environment with restricted mobility within cells (Figure 4). It should be noted, however, that a very

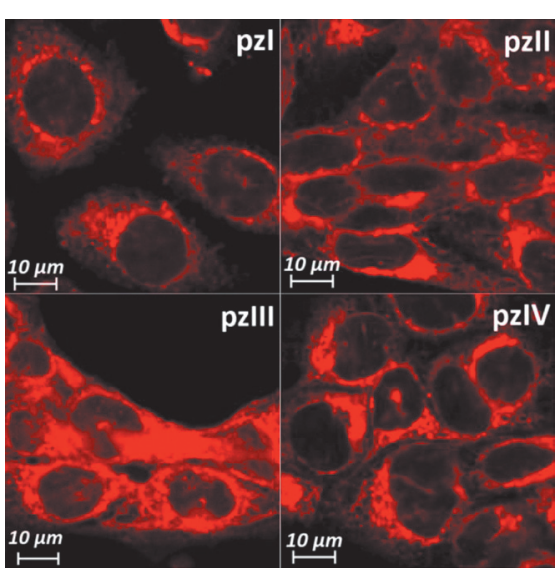

Figure 4. Confocal images of A431 cells after the incubation for one hour with pzI and four hours with pzII-pzIV. The compound concentration is $5 \mu \mathrm{M}$. 
strong sensitivity of the quantum yield of this porphyrazine to the viscous properties of the $\mathbf{p z}$ environment as well as the presence of proteins and other macromolecules which can potentially bind porphyrazines makes impossible a direct calculation of the coefficients of dye accumulation in cells. The study of $\mathbf{p z}$ intracellular localization after incubation of cells in $\mathbf{p z}$ containing medium revealed $\mathbf{p z}$ accumulation in perinuclear region of cytoplasm. The main sites of pzIV localization are intracellular membranes, mainly endoplasmic reticulum and Golgi apparatus (Figure 5).

We have established that first synthesized cyano-aryl porphyrazine containing polycyclic phenanthryl peripheral substituents showed strongly enhanced potential as a photosensitizer. It was demonstrated with quantitative assessment of its dark and photoinduced cytotoxicities against human epidermoid carcinoma A431 cell line. A widely used experimental procedure was applied for estimation the half maximal inhibitory concentration inducing $50 \%$ cell growth inhibition (or death). This parameter was measured both in the dark $\left(\mathrm{IC}_{50}(\right.$ dark $\left.)\right)$ and under irradiation $\left(\mathrm{IC}_{50}\right.$ (light)) (Figure 6). The $\mathrm{IC}_{50}$ values are given in Table 2. We observe noticeable enhancement
Table 2. Dark and photoinduced cytotoxicity $\left(\mathrm{IC}_{50}\right)$ of porphyrazines.

\begin{tabular}{cccc}
\hline Porphyrazine & $\begin{array}{c}\mathrm{IC}_{50}(\text { light }), \\
\mu \mathrm{M}\end{array}$ & $\begin{array}{c}\mathrm{IC}_{50}(\text { dark }), \\
\mu \mathrm{M}\end{array}$ & $\begin{array}{c}\mathrm{IC}_{50}(\text { dark }) / \\
\mathrm{IC}_{50}(\text { light })\end{array}$ \\
\hline pzI $^{[12]}$ & 0.80 & 6.9 & 9 \\
pzII & 0.40 & 23 & 58 \\
pzIII & 0.14 & 9.5 & 68 \\
pzIV & 1.10 & 200 & 182 \\
\hline
\end{tabular}

of photocytotoxicity for cyano-aryl porphyrazines pzII and pzIII that, presumably, is a result of their peripheral aromatic system extension. Simultaneously, we can observe the most impressive increase of cell survival rate in the dark for cell cultures loaded with pzIV. It should be noted the intrinsic cytotoxicity of pzIV (i.e., cytotoxicity not related to photodynamic process) is lower by more than two orders of magnitude than that of previously described pzI. It demonstrates considerably higher predominance of photoinduced cytotoxicity over cytotoxicity in the dark. So, pzIV demonstrates the best ratio $\mathrm{IC}_{50}$ (dark)/ $/ \mathrm{IC}_{50}$ (light)
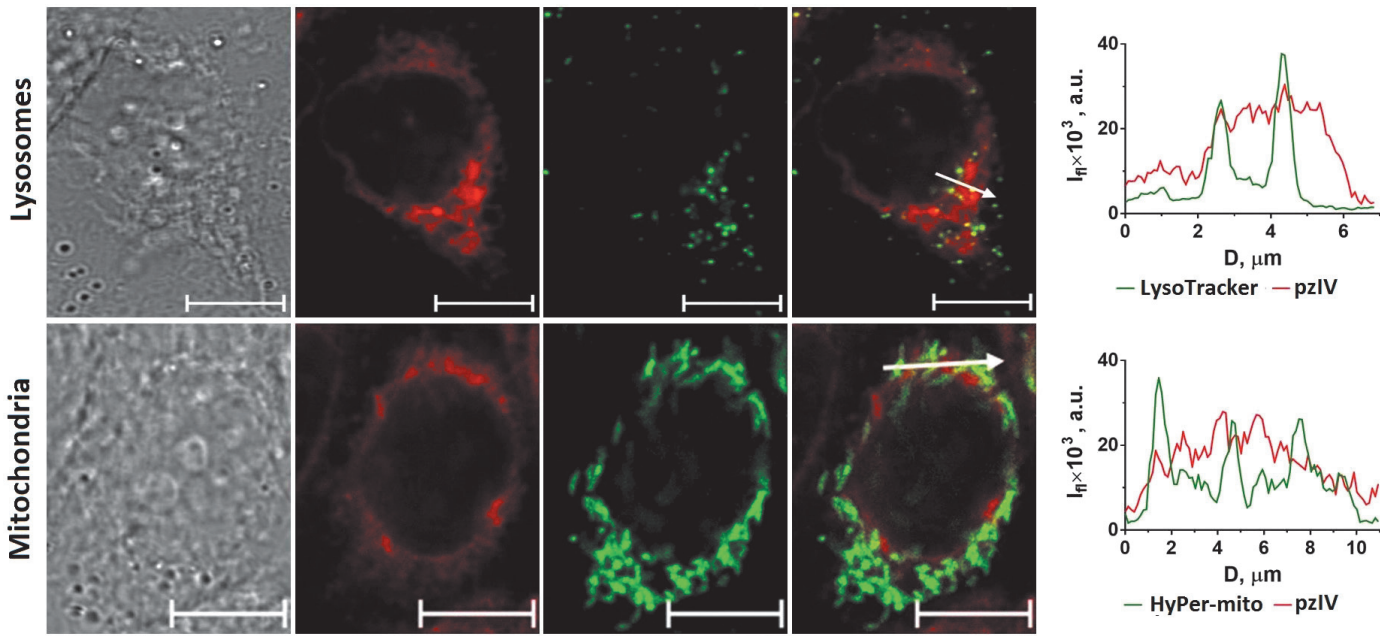

- LysoTracker - pzIV
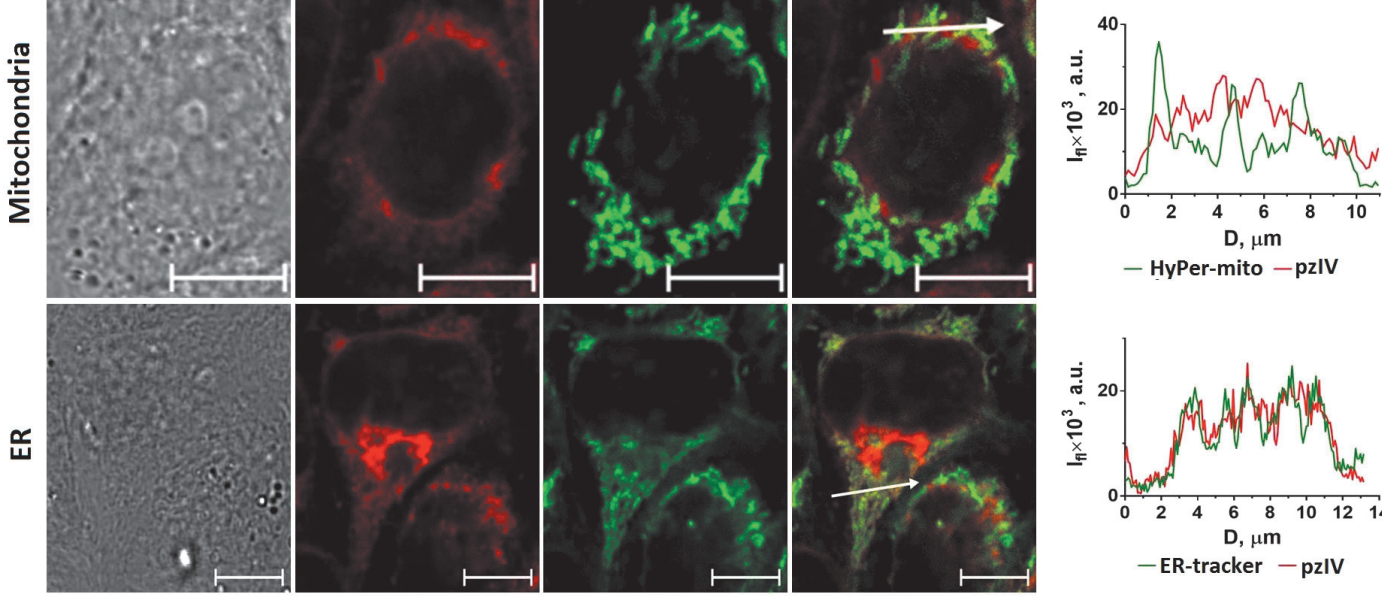

- HyPer-mito - pzIV
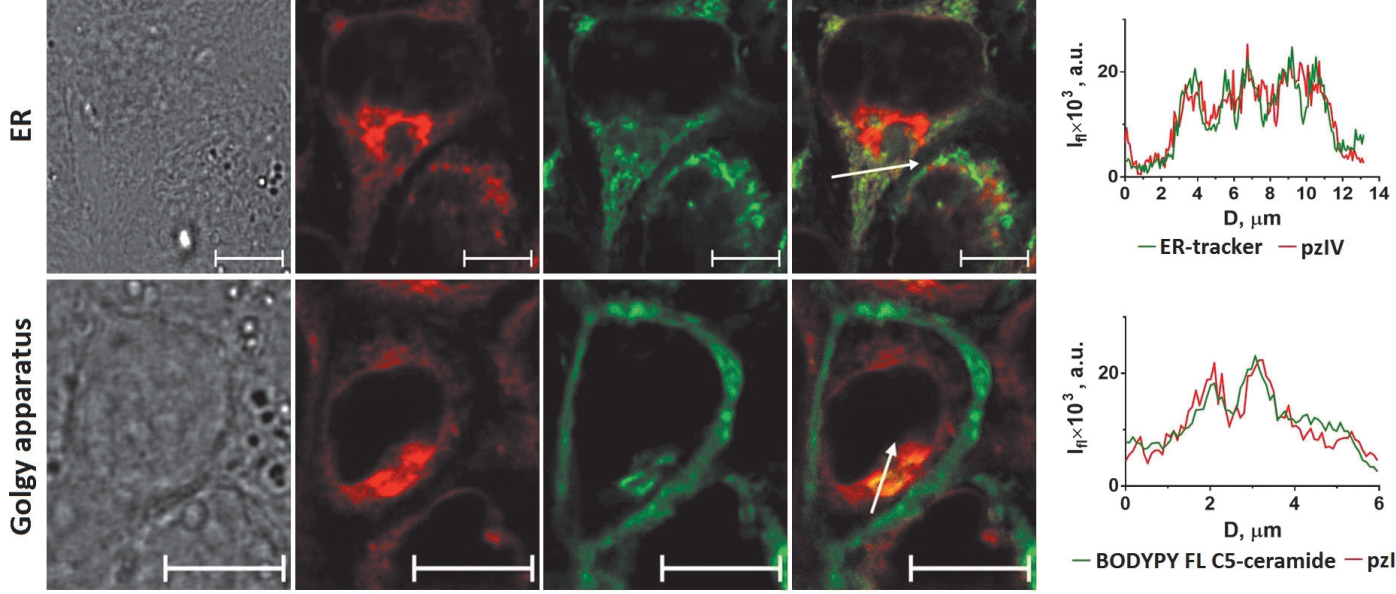

- ER-tracker - pzIV

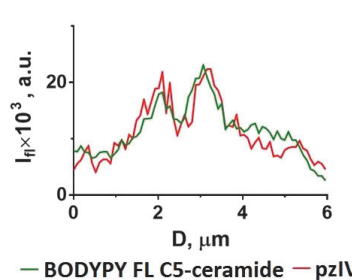

Figure 5. Analysis of intracellular localization of pzIV in A431 cells. The cells were incubated with pzIV (5 $\mu \mathrm{M})$ for 4 hours and then stained with the following dyes: LysoTracker Green for lysosomes; ER-Tracker for ER and BODYPY FL C5-ceramide complexed to BSA. For mitochondria visualization the genetically transformed A431 cells expressing mitochondria-targeted fluorescent protein HyPer-mito were used. Left: confocal images in transmitted light, red fluorescence of pzIV, green fluorescence of the organelle dye and merged fluorescent channels are presented. Right: Fluorescence signal profiles along the lines indicated by the white arrow on the images with superimposed fluorescence channels are shown. $\mathrm{I}_{\mathrm{fl}}$ : fluorescence intensity; D: distance along the specified segment. Scale bars, $10 \mu \mathrm{m}$. 
or so-called potential therapeutic index that is quantitative parameter characterizing the efficiency of a photosensitizer. This parameter reflects the range of safe administration of a drug and is the ratio of the toxic dose to the effective therapeutic dose. Thus, in spite pzIV showed a little smaller $\mathrm{IC}_{50}$ under illumination with light (Table 2) that pigment might be expected as substantially more efficient photodynamic agent in PDT. In general, we believe the value of potential therapeutic indexes for cyano-aryl porphyrazines with polycyclic aryl substituents is the important factor for the choice of macrocycle design approach.

It should be noted that cyano-aryl porphyrazines demonstrate the unique for tetrapyrrol macrocycles feature of photophysical behaviour. They combine the strong photodynamic activity with fluorescent molecular rotors properties. The term "fluorescent molecular rotors" (FMR) is commonly applied to the fluorescent dyes which undergo the intramolecular twisting motion upon the excitation with light. Depending on the rigidity of the environment and the segmental mobility of molecular rotors, their relaxation to the ground state after photoexcitation can be accomplished in two ways: by means of emission of photons with red-shifted wavelength and through radiationless ("dark") state, when part of the excitation energy is dissipated as a result of the intramolecular motion of the rotor molecule fragments. Thus, the emission properties of molecular rotortype dyes are strongly viscosity-dependent, and the solvent viscosity is the primary determinant of the fluorescence parameters (quantum yield and decay time) of such the dyes. It is known that viscosity is an important parameter determining the diffusion rate of species in condensed media. In biological systems, it can change as a consequence of disease, malfunction and cell death. ${ }^{[18]}$

The dependence of fluorescence quantum yield $\left(\Phi_{f}\right)$ and decay time $\tau_{\mathrm{f}}$ on viscosity $(\eta)$ is described by the simple Förster-Hoffman Equations (2)-(3): $:^{[19]}$

$$
\begin{aligned}
& \Phi_{\mathrm{f}}=\mathrm{z} \eta^{\alpha} \\
& \tau_{\mathrm{f}}=\mathrm{zk}_{\mathrm{r}}^{-1} \eta^{\alpha}
\end{aligned}
$$

The molecular rotor approach can be used for viscosity sensing in a wide range of biological environments, including those present within a living cell.

Our recent papers ${ }^{[11,13,20]}$ presented the photophysical proofs that the cyano-aryl porphyrazine tetrapyrrol dyes pzI, pzII and pzIII were in fact fluorescent molecular rotors that could be potentially utilized to determine the local intracellular viscosity even under conditions of its dynamic change, for example, under the conditions of photodynamic therapy. Similarly, we found the significant dependence of the fluorescence intensity of pzIV on the medium viscosity (Figure 7A). In addition, the graph of an average fluorescence lifetime plotted against the viscosity showed an acceptable correspondence to Förster-Hoffmann equation with the slope $\alpha \sim 0.4$. For the molecular rotors this value ranges between $1 / 3$ and $2 / 3$, so pzIV can be attributed to this type of fluorophores. ${ }^{[21]}$

The slope $\alpha$ for pzIV is significantly less than this for pzI framed by single aromatic rings that may be explained by larger size of polycyclic phenanthryl groups inhibiting rotation (Table 1). But we didn't observe any noticeable
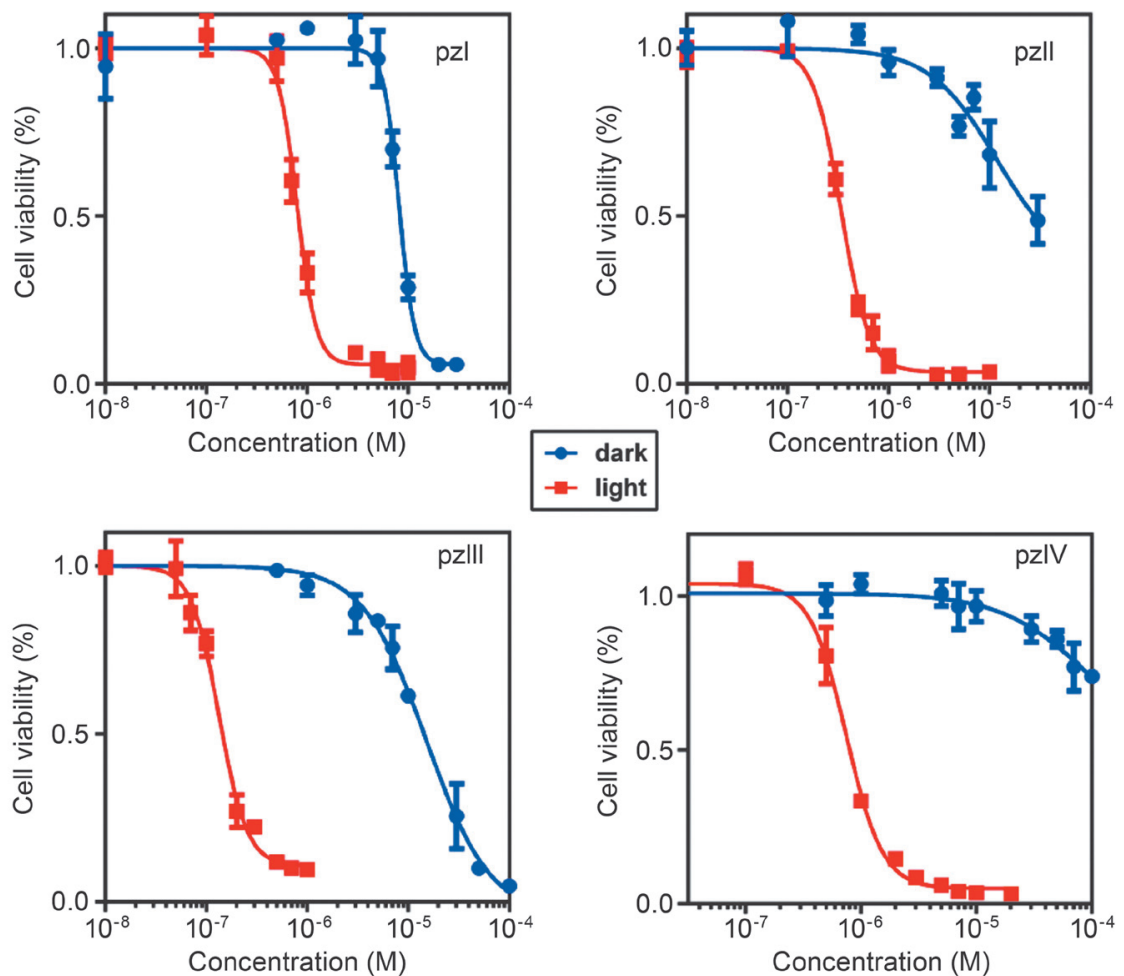

Figure 6. Dark and photoinduced cytotoxicity of pzI-pzIV towards A431 cell line as a function of photosensitizer concentration. The cells were incubated with porphyrazines for $4 \mathrm{~h}$ and were exposed to wavelengths of $615-635 \mathrm{~nm}$, at the irradiation doses of $20 \mathrm{~J} / \mathrm{cm}^{2}$ at the power density of $20 \mathrm{~mW} / \mathrm{cm}$. For dark cytotoxicity assessment, the plate was kept without irradiation. The errors bars denote one standard deviation from a minimum of 3 replicates. 

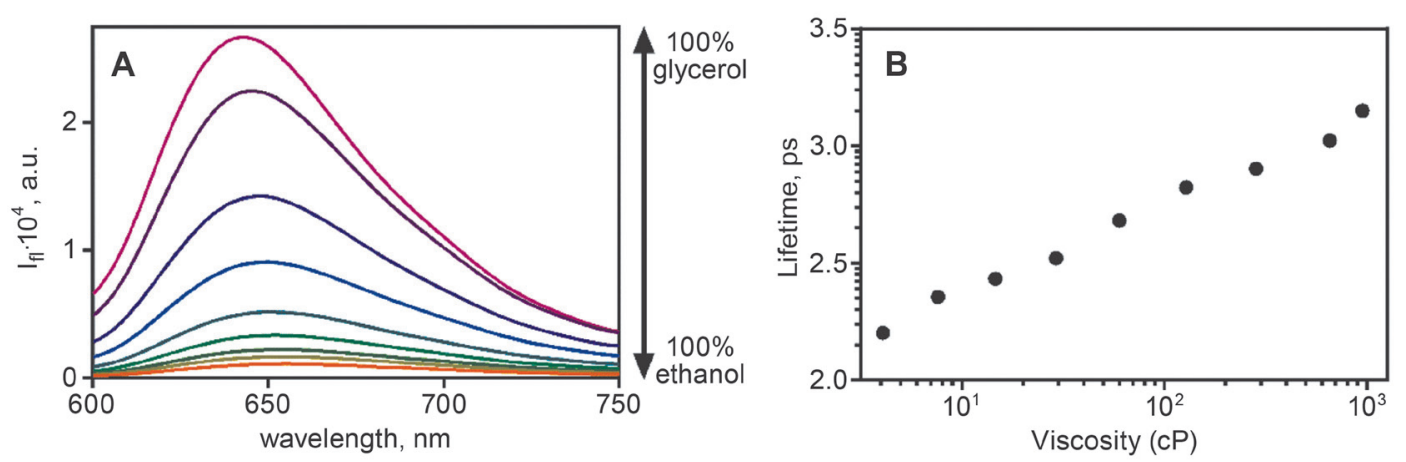

Figure 7. A: Enhancement of fluorescence intensity of pzIV in the different ethanol/glycerol mixtures. B: An average fluorescence lifetime of pzIV vs. viscosity.

differences in rotor properties for pzII, pzIII and pzIV. Thus, rotor properties of pzIV possess pronounced sensitivity of fluorescence parameters to the local viscosity and potentially can be used as an intracellular viscosity sensor.

\section{Conclusions}

The new cyano-aryl porphyrazine containing phenanthryl polycyclic aromatic groups in the peripheral framing of macrocycle (pzIV) has been developed. It showed noticeable cellular uptake and the considerable photodynamic activity. It was found that potential therapeutic index $\left(\mathrm{IC}_{50}(\mathrm{dark}) / \mathrm{IC}_{50}(\right.$ light $\left.)\right)$ of $\mathbf{p z I V}$ is much greater than that for another described cyano-aryl porphyrazines. ${ }^{[11-13,22]}$ Additionally, this tetrapyrrol macrocycle as the most of cyano-aryl porphyrazines demonstrates photophysical behaviour of the fluorescent molecular rotor, i.e., high sensitivity of the fluorescence parameters to local viscosity. We believe that the combination of properties of highly efficient photosensitizer in PDT and the sensitive intracellular viscosity sensor enable significant enhancement of the pzIV functionality as a potential agent of optical theranostics.

Acknowledgements. This work was supported by Russian Science Foundation (project № 18-73-00194) in the part of chemical synthesis and analysis of photophysical properties and the Ministry of Science and Higher Education of the Russian Federation (Contract 6.3099.2017) in the part of cell studies.

\section{References}

1. Berg K., Selbo P.K., Weyergang A., Dietze A., Prasmickaite L., Bonsted A., Engesaeter B.O., Angell-Petersen E., Warloe T., Frandsen N., Hogset A. J. Microsc. 2005, 218, 133-147.

2. Dolmans D.E., Fukumura D., Jain R.K. Nat. Rev. Cancer 2003, 3, 380-387.

3. Dougherty T.J., Gomer C.J., Henderson B.W., Jori G., Kessel D., Korbelik M., Moan J., Peng Q. J. Natl. Cancer Inst. 1998, 90, 889-905.
4. Ferlay J., Soerjomataram I., Dikshit R., Eser S., Mathers C., Rebelo M., Parkin D.M., Forman D., Bray F. Int. J. of Cancer 2015, 136(5), E359-86.

5. Castano A.P., Demidova T.N., Hamblin M.R. Photodiagnosis and Photodynamic Therapy 2004, 1(4), 279-293.

6. Henderson B.W., Dougherty T.J. J. Photochem. Photobiol. 1994, 55, 145-157.

7. Benov L. Photodynamic Therapy: Current Status and Future Directions. Medical Principles and Practice 2015, 24, 14-28.

8. Trivedi E.R., Harney A.S., Olive M.B., Podgorski I., Moin K., Sloane B.F., Barrett A.G.M., Meade T.J., Hoffman B.M. Proc. Natl. Acad. Sci. USA 2010, 107, 1284-1288.

9. Vesper B.J., Lee S., Hammer N.D., Elseth K.M., Barrett A.G.M., Hoffman B.M., Radosevich J.A. J. Photochem. Photobiol. B: Biology 2006, 82(3), 180-186.

10. Michel S.L.J., Hoffman B.M., Baum S.M., Barrett A.G.M. Prog. Inorg. Chem. 2001, 50, 473.

11. Lermontova S.A., Grigoryev I.S., Shilyagina N.Y., Peskova N.N., Balalaeva I.V., Shirmanova M.V., Klapshina L.G. Russ. J. Gen. Chem. 2016, 86, 1330-1338.

12. Lermontova S.A., Grigor'ev I.S., Peskova N.N., Ladilina E.Y., Balalaeva I.V., Klapshina L.G., Boyarskii V.P. Russ. J. Gen. Chem. 2017, 87, 479-484.

13. Izquierdo M.A., Vysniauskas A., Lermontova S.A., Grigoryev I.S., Shilyagina N.Y., Balalaeva I.V., Klapshina L.G., Kuimova M.K. J. Mater. Chem. B 2015, 3, 1089-1096.

14. Yakimansky A.V., Meleshko T.K., Ilgach D.M., Bauman M.A., Anan'eva T.D., Klapshina L.G., Lermontova S.A., Balalaeva I.V., Douglas W.E. J. Polym. Sci. Part A Polym. Chem. 2013, 51, 4267-4281.

15. Shilyagina N.Y., Plekhanov V.I., Shkunov I.V., Shilyagin P.A., Dubasova L.V., Brilkina A.A., Sokolova E.A., Turchin I.V., Balalaeva I.V. Sovremennye Tekhnologii v Meditsine 2014, 6, 15-22 (in Russ.).

16. Mosmann T. J. Immunol. Methods 1983, 65, 55-63.

17. Lakowicz J.R. Principles of Fluorescence Spectroscopy, 3rd edn. Springer US, 2006, 63-95.

18. Deliconstantinos G., Villiotou V., Stavrides J.C. Biochem. Pharmacol. 1995, 49, 1589-1600.

19. Förster T., Hoffmann G. Z. Phys. Chem. 1971, 75(1-2), 63.

20. Lermontova S.A., Klapshina L.G., Grigoryev I.S., Balalaeva I.V., Shilyagina N.Y., Peskova N.N. Patent RU 2665471, 2017.

21. Kuimova M.K. Chimia 2012, 66, 159-165.

22. Shilyagina N.Y., Peskova N.N., Lermontova S.A., Brilkina A.A., Vodeneev V.A., Yakimansky A.V., Klapshina L.G., Balalaeva I.V. J. Biophotonics 2016, 10, 1189-1197. 